\title{
PENGARUH ANTARA KONSEP DIRI DAN KECERDASAN EMOSI TERHADAP PERILAKU PROSOSIAL PADA REMAJA
}

\author{
Minggus Salvinus Masela \\ Fakultas Psikologi, Universitas Wisnuwardhana Malang \\ alvinmasela@gmail.com
}

\begin{abstract}
Abstrak: Perkembangan perilaku prososial yang baik dengan semua orang berkaitan dengan konsep diri dan kecerdasan emosi. Penelitian ini bertujuan untuk mengetahui keterkaitan antara konsep diri dan kecerdasan emosi terhadap perilaku prososial. Subyek penelitian ini adalah 100 siswa IPA-IPS kelas I dan II SMA Taman Harapan Malang. Data penelitian ini dikumpulkan dengan menggunakan skala konsep diri, skala kecerdasan emosi dan skala perilaku prososial yang disusun oleh peneliti. Hipotesis dianalisa dengan program SPSS 20. Hasilnya menunjukkan bahwa konsep diri dan kecerdasan emosi berpengaruh secara signifikan terhadap perilaku prososial di mana nilai $F$ sebesar 0,108 pada nilai $p$ sebesar $0,000(p>0,01)$. Koefisien determinasi sebesar 97, sehingga hal ini berarti kedua variabel bebas (konsep diri dan kecerdasan emosi) memberikan sumbangan efektif secara bersama-sama sebesar $97 \%$ kepada variabel terikat (perilaku prososial). Prosentase determinasi menunjukkan bahwa kecerdasan emosi lebih memberikan sumbangan efektif $(0,146 \%)$ daripada konsep diri sebesar $(-.456 \%)$.
\end{abstract}

Kata Kunci: Perilaku Prososial, Konsep Diri, Kecerdasan Emosi.

Abstract: The development of good prosocial behavior with everyone is related to self-concept and emotional intelligence. This study aims to determine the relationship between self-concept and emotional intelligence on prosocial behavior. The subjects of this study were 100 students of IPA-IPS class I and II Taman Harapan Malang High School. The data of this study were collected using a scale of self-concept, emotional intelligence scale and prosocial behavior scale compiled by researchers. The hypothesis was analyzed with the SPSS 20. The results show that self-concept and emotional intelligence significantly influence prosocial behavior where the $F$ value is 0,108 at a $p$ value of 0,000 ( $p>0.01$ ). The coefficient of determination is 97 , so this means that both independent variables (self-concept and emotional intelligence) contribute effectively together by $97 \%$ to the dependent variable (prosocial behavior). The percentage of determination shows that emotional intelligence contributes more effectively $(0.146 \%)$ than self-concept $(-.456 \%)$.

Keywords: Prosocial Behavior, Self-Concept, Emotional Intelligence.

\section{PENDAHULUAN}

Walgito (2003), mengemukakan bahwa manusia tidak dapat melepaskan diri dari lingkungannya.Lingkungan dalam hal ini baik lingkungan fisik maupun lingkungan psikis.Lingkungan fisik, yaitu alam benda-benda yang konkret, sedangkan lingkungan psikis adalah jiwa raga individu-individu dalam lingkungan, ataupun lingkungan rohaniah.

Sebagai makhluk sosial, manusia tidak dapat lepas dari hubungan dengan manusia lainnya, untuk itu manusia membutuhkan interaksi dengan orang lain yang di dalamnya terdapat hubungan timbal balik antar individu. Pada kehidupan sehari- 
hari, seseorang yang dikatakan mandiri dan pintarpun pada suatu saat pasti akan membutuhkan pertolongan atau bantuan dari orang lain. Sekarang kepedulian orang terhadap orang lain pun mulai menurun. Masyarakat sekarang lebih mementingkan dirinya sendiri daripada orang lain, padahal budaya kita sebagai orang timur adalah kekeluargaan dan gotong-royong, namun hal itu sudah jarang ditemukan dalam kehidupan masyarakat (Asih \& Margareta,2010). Lebih lanjut, hilangnya sikap prososial ini terjadi pada setiap lapisan masyarakat dan tidak menutup kemungkinan terjadi pada remaja.Remaja sebagai agen perubahan seharusnya memiliki perilaku prososial yang baik, yang merupakan cermin dan sebagai contoh bagi masyarakat (Asih \& Margareta,2010). Memperhatikan kontribusi positif perilaku prososial bagi individu, terutama dalam mencegah terjadinya konflik sosial, maka perilaku prososial perlu dibangun dan dipertahankan keberadaannya. Jika perilaku prososial tidak dilestarikan maka kemungkinan besar akan terjadi konflik sosial. Adanya konflik sosial yang dibiarkan, atau tanpa adanya kontrol dari masyarakat, akan berakibat munculnya perilaku yang cenderung ke arah negatif dan bertentangan dengan norma atau melawan aturan, hukum, etika, nilai, dan moral yang berlaku di masyarakat. Remaja adalah cikal-bakal untuk membantu kehidupan masyarakat di masa yang akan datang menjadi lebih baik dan bukan sebaliknya yaitu terbiasa dengan perilaku yang tidak prososial atau bahkan anti sosial.

Seiring dengan kemajuan teknologi informasi pada masa sekarang nilai-nilai perilaku prososial di dalam kehidupan sehari-hari khususnya di Indonesia.Menunjukkan perkembangan yang cukup menarik.Remaja dapat tergugah dengan berbagai situasi yang dapat menimbulkan tindakan perilaku prososial. Media massa seperti televisi dan internet memberikan antusiasme yang tinggi pada remaja untuk melakukan tindakan perilaku prososial.

Sear (2003) menyatakan bahwa masing-masing individu bukanlah sematamata makhluk tunggal yang mampu hidup sendiri, melainkan sebagai makhluk sosial yang sangat bergantung pada individu lain. Seseorang dikatakan berperilaku prososial jika individu tersebut menolong individu lain tanpa memperdulikan moti-motif si penolong, timbul karena adanya penderitaan yang dialami oleh orang lain dalam bentuk aktivitas: saling membantu, saling menghibur, persahabatan, penyelamatan, pengorbanan, kemurahan hati, dan saling membagi.

Eisenberg dan Wang (dikutip dari Santrock,2007) mengemukakan bahwa seseorang memiliki perilaku prososial bila dirinya memiliki kepedulian terhadap keadaan dan hak orang lain, perhatian dan empati pada orang lain serta berbuat sesuatu yang memberikan manfaat bagi orang lain. Perilaku prososial dapat memberikan pengaruh bagaimana individu melakukan interaksi sosial.

Papalia (2002) menyatakan rasa ketergantungan seperti kebutuhan untuk dibantu ketika terkena musibah muncul secara spontan. Sedangkan rasa iba bagi orang lain yang melihat juga akan muncul secara spontan tanpa dapat dibendung. Hanya saja prosentase perilaku munculnya prososial sangat kecil karena sangat terkait dengan faktor-faktor serta aspek-aspek yang berperan dalam terciptanya perilaku prososial.

Hilangnya sikap prososial juga terjadi pada Siswa SMA Taman Harapan Malang sebagai agen perubahan seharusnya memiliki perilaku prososial yang baik dan sebagai contoh bagi masyarakat. Namun pada kenyataannya, kebanyakan siswa di SMA Taman Harapan Malang telah ditemukan berbagai indikasi sikap dan perilaku yang melanggar nilai-nilai sosial 
baik di sekolah maupun di masyarakat seperti, adanya kelompok-kelompok siswa yang bisa disebut sebagai geng yang memiliki aturannya sendiri dan kebanyakan dari mereka melakukan bullying, melakukan kekerasan fisik terhadap yang lemah, terlibat dalam kenakalan remaja antar kelompok atau sekolah, melakukan intimidasi terhadap kaum minoritas, mengucapkan kata-kata makian terhadap sesama teman, sikap tidak sopan terhadap orang yang lebih dewasa secara usia, berkurangnya sikap saling menolong dalam memberikan penjelasan pelajaran kelas, sikap individualitik dan sikap saling mengajak untuk tidak mengikuti pembelajaran kelas alias bolos.

Meichati (1990) mengemukakan konsep diri merupakan internal frame of reference, yaitu acuan bagi tingkah laku dan cara penyesuaian seseorang. Orang yang memiliki konsep diri positif akan menghasilkan perilaku yang positif, dan akan mudah melakukan kontrol terhadap perilakunya sendiri dalam lingkungan. Sebaliknya, orang yang memiliki konsep diri negatif akan menunjukkan perilaku yang negatif pula dalam pergaulan dan sulit untuk melakukan kontrol atau mengendalikan diri jika menghadapi suatu situasi tertentu.

Konsep diri yang dimiliki remaja akan mempengaruhi perilakunya dalam hubungan prososial dengan individu lain. Sesuai dengan pendapat Aditomo dan Retnowati (2004) yang mengemukakan bahwa konsep diri berpengaruh dalam perilaku remaja dalam kehidupan seharihari, remaja dengan konsep diri rendah cenderung berperilaku negatif dalam perilakunya dan merasa tidak dihargai, tidak diterima dan diperlakukan kurang baik oleh orang lain, sebaliknya remaja dengan konsep diri tinggi cenderung berperilaku positif dalam perilakunya, individu mampu melihat dirinya berharga, diterima dan diperlakukan baik oleh orang lain. Begitu pula dalam konteks perilaku prososial, konsep diri diperlukan agar remaja mampu melakukan tindakan yang menuntut pengorbanan (ikhlas) untuk membantu orang lain sesuai dengan apa yang diharapkan.

Seseorang yang memiliki konsep diri yang baik, maka memiliki gambaran tentang dirinya sendiri secara positif, sedangkan seseorang yang konsep dirinya negatif cenderung kurang berhasil dalam melaksanakan penyesuaian prososialnya.Dengan demikian konsep diri merupakan hal yang penting yang patut diperhatikan dalam melakukan perilaku prososial.

Remaja diharapkan memiliki konsep diri yang positif sehingga mampu memahami keadaan diri sendiri serta menghayati nilai-nilai moral yang berlaku di masyarakat, karena dengan adanya pemahaman terhadap diri sendiri dan penghayatan terhadap nilai-nilai tersebut remaja akan lebih mudah untuk menumbuhkan kepekaan perilaku prososial. Namun kenyataan yang terjadi nilai-nilai prososial di masyarakat semakin lama semakin menurun, banyak remaja apatis, tidak peduli dengan lingkungan sekitar, tidak menghormati orang tua serta sering melakukan perbuatan-perbuatan yang merugikan diri sendiri dan orang lain.

Fenomena menurunya nilai-nilai prososial didukung oleh hasil penelitian yang dilakukan Hamidah (2002) ditujuh daerah di JAwa Timur yang menunjukkan adanya indikasi penurunan kepedulian sosial dan kepekaan terhadap orang lain dan lingkungan. Remaja Nampak lebih mementingkan diri sendiri dan keberhasilannya tanpa banyak mempertimbangkan keadaan orang lain di sekitarnya.Hal ini menyebabkan remaja menjadi semakin individualis dan sikap sosial yang dimiliki semakin pudar.Lebih lanjut Hamidah (2002) pada penelitiannya menyatakan orang cenderung egois dan 
berbuat untuk mendapatkan suatu imbalan (materi).Sikap ini menimbulkan ketidak pedulian terhadap lingkungan sosialnya.Dampaknya terutama di kot-kota besar, remaja menampakkan sikap materialistic, acuh pada lingkungan sekitar dan cenderung mengabaikan norma-norma yang tertanam sejak dulu.

Faktor lain yang juga mempengaruhi munculnya perilaku prososial juga adalah kecerdasan emosional yang dimiliki oleh individu. Hal ini sejalan dengan hasil penelitian Sabiq dan Djalali (2012), dengan hanalisa regresi menunjukkan harga koefisien $\mathrm{F}=111,993$ pada $\mathrm{p}=0,000(\mathrm{p}<$ $0,01)$ sehingga dapat disimpulkan bahwa secara bersama-sama variabel antara kecerdasan emosi, kecerdasan spiritual berkorelasi sangat signifikan dengan perilaku prososial.

Arbadiati \& Kurniati (2007) mengatakan bahwa individu yang memiliki kecerdasan emosional pasti memiliki kemampuan dalam merasakan emosi, mengelola dan memanfaatkan emosi secara tepat sehingga memberikan kemudahan dalam menjalani kehidupan sebagai makhluk sosial.

Kecerdasan emosi dapat diartikan dengan kemampuan untuk "menjinakkan" emosi dan mengarahkan kepada hal-hal yang lebih positif. Seseorang dapat melakukan sesuatu dengan didorong oleh emosi, dalam arti bagaimana yang bersangkutan dapat menjadi begitu rasional pada suatu saat dan menjadi begitu tidak rasional pada saat yang lain.

\section{Perilaku Prososial}

Perilaku prososial diartikan sebagai suatu kepedulian terhadap sesame apapun motifnya. Menurut Baron \& Byrne (2005) mengatakan bahwa perilaku prososial adalah suatu tindakan menolong yang menguntungkan orang lain tanpa harus menyediakan suatu keuntungan langsung pada orang lain yang melakukan tindakan tersebut, dan mungkin bahkan melibatkan suatu resiko bagi orang yang menolong. Gerungan (2000) menyatakan bahwa perilaku prososial mencakup perilaku yang menguntungkan orang lain yang mempunyai konsekuensi sosial yang positif sehingga akan menambah kebaikan fisik maupun psikis.Lebih jauh lagi, pengertian perilaku prososial mencakup tindakantindakan: membagi (sharing), kerjasama (cooperative), menyumbang (donating), menolong (helping), kejujuran (honesty), kedermawanan (generosity), serta mempertimbangkan hak dan kesejahteraan orang lain (Eisenberg \& Musse, Baron \& Byrne,2005).

Menurut Dayakisni \& Hudaniah (2003) membatasi perilaku prososial sebagai perilaku yang memiliki intensi untuk mengubah keadaan fisik atau psikologis penerima bantuan dari kurang baik menjadi lebih baik, dalam arti secara material maupun psikologis.

Walgito (2003) yang mengemukakan bahwa manusia tidak dapat melepaskan diri dari lingkungannya.Lingkungan dalam hal ini baik lingkungan fisik maupun lingkungan psikis.Lingkungan fisik, yaitu alam benda-benda yang konkret, sedangkan lingkungan psikis adalah jiwa raga individu-individu dalam lingkungan, ataupun lingkungan rohaniah.

Tipe perilaku prososial yang dibuat oleh Carlo dan Randall (2002) dalam jurnal The Development of a Measure of Prosocial Behaviors for Late Adolescent, menjelaskan bahwa ada 3 aspek perilaku prososial yaitu:

a. Emotional: yaitu tindakan seseorang menolong bila situasi sangat emosional bagi penolong.

b. Public: yaitu tindakan seseorang menolong untuk mendapatkan penghargaan dari orang lain.

c. Anonymous: yaitu tindakan seseorang menolong dengan tidak memberita identitas (korban tidak tahu identitas penolong). 


\section{Konsep Diri}

Gunawan, (2005) menyebutkan bahwa seseorang yang mempunya konsep diri positif akan menjadi individu yang mampu memandang dirinya secara positif, berani mencoba dan mengambil resiko, selalu optimis, percaya diri, dan antusias menetapkan arah dan tujuan hidup.

Craven (2002) menyatakan bahwa konsep diri yang positif akan berhubungan dengan afeksi terhadap diri sendiri (self worth) dan penerimaan diri perasaan terhadap diri sendiri yang positif disertai penerimaan diri, akan membuat perkembangan individu dalam konteks kemasyarakatan, termasuk dalam dunia kerja, menjadi optimal melalui pengenalan tahap-tahap perkembangan dengan pemahaman yang cerdik, pengambilan keputusan yang matang, pengaturan diri yang bertanggung jawab dan moral yang otonom (Craven, 2002).

Para teoris kontrol sosial menyatakan bahwa yang menampakkan perilaku antisosial adalah remaja yang memiliki konsep diri rendah. Perspektif kontrol sosial menyatakan konsep diri mempengaruhi kontrol diri. Individu dengan kontrol diri rendah memiliki kekuatan ego rendah, kurang mampu menunda kepuasan (kurang sabar), kurang toleran pada frustrasi dan lebih impulsif. Perilaku sosial yang tidak dapat akan tampak ketika derajad kontrol sosial tidak cukup kuat menolak godaan yang ingin langsung dipuaskan (Hay, 2000).

Brooks dalam Rakhmat (2002) menyatakan ketiga aspek konsep diri adalah sebagai berikut :

1) Karakteristik konsep diri penampilan fisik, yaitu bagaimana cara seseorang menilai dirinya secara fisik.

2) Karakteristik konsep diri secara psikis, bagaimana cara seseorang menilai dirinya secara psikis.

3) Karakteristik konsep diri secara sosial, bagaimana cara seseorang menilai dirinya dalam siatuasi sosial.

\section{Kecerdasan Emosi}

Seseorang yang telah mencapai kecerdasan dapat mengendalikan emosinya. Emosi yang terkendali menyebabkan orang mampu berpikir secara lebih baik, melihat persoalan secara objektif (Walgito,2004).

Salovey (2007) mendefinisikan kecerdasan emosi sebagai kemampuan untuk mengenali perasaan, meraih dan membangkitkan perasaan untuk membantu pikiran, memahami perasaan dan maknanya, serta mengendalikan perasaan secara mendalam sehingga membantu perkembangan emosi dan intelektual.

Pengertian tersebut sejalan dengan pengertian emotional intelligence dari Goleman (2002), yang mengungkapkan bahwa kecerdasan emosional adalah kemampuan individu mengatur emosinya, memotivasi diri sendiri serta bertahan dalam menghadapi frustrasi, mengatur dan mengendalikan suasana hati.

Pengertian yang serupa diungkapkan oleh Cherry (2002), yang secara singkat mengungkapkan bahwa emotional intelligence menunjuk pada kemampuan untuk memahami, mengendalikan, dan mengevaluasi emosi.

Jadi dari teori-teori di atas dapat disimpulkan bahwa kecerdasan emosional adalah kemampuan individu untuk bertindak secara tepat dalam menyelesaikan permasalahan, mampu mengendalikan luapan emosi dan mampu mengantisipasi secara kritis setiap permasalahan sesuai dengan situasi dan kondisi.

Penyusunan blue print skala kecerdasan emosi disusun berdasarkan aspek-aspek yang dikemukakan oleh Salovey (Goleman,2002) yaitu:

a. Mengelola emosi: Kemampuan untuk menangani perasaan agar dapat terungkap dengan tepat.

b. Memotivasi diri sendiri: Kemampuan menata emosi sebagai alat untuk mencapai tujuan. Menahan diri 
terhadap kepuasan dan mengendalikan dorongan hati merupakan landasan keberhasilan dalam berbagai bidang.

c. Mengenali emosi orang lain: Kemampuan untuk mengenali emosi orang lain disebut juga sebagai empati. Orang yang empatik lebih mampu menangkap sinyal-sinyal sosial yang tersembunyi yang mengisyaratkan apapun yang dibutuhkan dan dikehendaki oleh orang lain.

d. Membina hubungan: Kemampuan individu untuk membentuk hubungan, dan merupakan keterampilan mengelola emosi orang lain.

\section{METODE}

\section{Subyek Penelitian}

Populasi dalam penelitian ini adalah Siswa SMA Taman Harapan Malang sebanyak 140 tahun ajaran 2019.

Jumlah sampel sebanyak 100 orang kelas 1 (satu), 35 dan kelas 2 (dua), kelas IPS-32 dan IPA-33 dan dalam pemilihan sampel menggunakan teknik simple random sampling, yaitu dengan menggunakan teknik acak sederhana yaitu mengundi daftar hadir dengan cara, setiap nama siswa dicatat di sebuah kertas yang hadir pada saat itu kemudian dimasukkan kedalam kaleng dan diacak. Peneliti kemudian mengambil nama-nama tersebut dari dalam kaleng sesuai dengan jumlah sampel yang telah ditentukan dan dipergunakan untuk mengisi skala atau aitem penelitian yang sudah disediakan oleh peneliti.

\section{Alat Ukur \\ Perilaku prososial dalam penelitian ini diukur dengan menggunakan skala perilaku prososial yang dikemukakan oleh Carlo dan Randall (2002) yang meliputi aspek emotional, public dan anonymous. Aitem skala berjumlah 30 butir aitem dengan koefisien validitas butir bergerak dari 0,306 sampai 0,690 dengan reliabilitas Alpha Cronbach sebesar 0,925.}

Konsep diri dalam penelitian ini diukur dengan menggunakan skala konsep diri yang dikemukakan oleh Brooks dan Rakhmat (2002) di mana aspek-aspek tersebut antara lain konsep diri fisik, konsep diri psikis, konsep diri sosial. Aitem skala berjumlah 36 butir aitem dengan koefisien validitas butir bergerak dari 0,376 sampai 0,753 dengan reliabilitas Alpha Cronbach sebesar 0,955 .

Kecerdasan emosi dalam penelitian ini diukur dengan menggunakan skala kecerdasan emosi yang dikemukakan oleh Salovey (Goleman,2002) yang meliputi aspek mengelola emosi, memotivasi diri sendiri, mengenali emosi orang lain, membina hubungan. Aitem skala berjumlah 30 butir aitem dengan koefisien validitas butir bergerak dari 0,322 sampai 0,763 dengan reliabilitas Alpha Cronbach sebesar 0,920 .

\section{HASIL}

Hasil komputasi ANAREG diperoleh F hitung sebesar 0, 108 dengan db 2:99 diperoleh tabel $F=9,264$ (1\%), sehingga $F$ hitung $0,108>$ Tabel $\mathrm{F}$ dengan nilai $\mathrm{p}$ sebesar $0,00 \quad(p<0,01)$. Temuan ini menunjukkan ada pengaruh signifikan bersama-sama antara konsep diri dan kecerdasan emosi terhadap perilaku prososial. Dengan demikian, hipotesis mayor yang berbunyi "ada pengaruh konsep diri dan kecerdasan emosi terhadap perilaku prososial" dapat diterima.

Hipotesis korelasi ditemukan hasil Freg di peroleh $\mathrm{F}$ hitung sebesar 0, 108 dengan $\mathrm{db}$ 1: 97 diperoleh $\mathrm{F}$ tabel 1\%= -.456 , sehingga $\mathrm{F}$ hitung $-.456<\mathrm{F}$ tabel $1 \%$ $<0,205$. Temuan ini menunjukkan tidak ada pengaruh yang signifikan antara konsep diri terhadap perilaku prososial. Dengan demikian, hipotesis minor yang berbunyi " tidak ada pengaruh konsep diri terhadap perilaku prososial" tidak dapat diterima.

Hipotesis korelasi ditemukan hasil Freg di peroleh F hitung sebesar 0, 108 
dengan $\mathrm{db}$ 1: 97 diperoleh $\mathrm{F}$ tabel 1\%= 0.146 sehingga $\mathrm{F}$ hitung $0.146>\mathrm{F}$ tabel $1 \%$ $\mathrm{p}<0,000$. Temuan ini menunjukkan ada pengaruh yang signifikan antara kecerdasan emosi terhadap perilaku prososial. Dengan demikian, hipotesis minor yang berbunyi "ada pengaruh kecerdasan emosi terhadap perilaku prososial" dapat diterima.

Hasil koefisien determinan (R2) diperoleh hasil sebesar .097 yang berarti sumbangan efektif yang diberikan oleh konsep diri dan kecerdasan emnosi sebesar $97 \%$, sehingga sumbangan efektif yang tersisa sebesar 3\% yang mana dipengaruhi oleh faktor lain.

Perhitungan sumbangan efektif menunjukkan bahwa konsep diri memberikan sumbangan sebesar $-.456 \%$ terhadap perilaku prososial, sedangkan kecerdasan emosi sebesar 0,146 terhadap perilaku prososial. Hal ini menunjukkan bahwa dalam menumbuhkan perilaku prososial positif, kecerdasan emosi lebih memberikan sumbangan efektif daripada konsep diri terhadap perilaku prososial.

Pembahasan

Hasil koefisien determinan (R Square) diperoleh hasil sebesar 0.097 yang berarti sumbangan efektif yang diberikan oleh konsep diri dan kecerdasan emosi sebesar 97\%, sehingga sumbangan efektif yang tersisa sebesar 3\% dipengaruhi oleh faktor lain. Berarti dalam meningkatkan perilaku prososial yang positif, kecerdasan emosi lebih memberikan sumbangan dibandingkan konsep diri. Terdapat hubungan yang positif antara konsep diri dan kecerdasan emosi terhadap perilaku prososial, dimana semakin tinggi atau positif konsep diri dan kecerdasan emosi maka akan semakin tinggi atau positif perilaku prososial yang dialami. Demikian pula sebaliknya semakin rendah atau negatif konsep diri dan kecerdasan emosi maka akan semakin rendah atau negatif perilaku prososial yang dialami.
Hasil penelitian telah menggambarkan bahwa terdapat unsur pengaruh mempengaruhi atau terdapat korelasi antara konsep diri dan kecerdasan emosi dengan perilaku prososial. Konsep diri memberikan sumbangan yang sangat sedikit, yang berarti siswa masih memiliki konsep diri yang terlihat lewat menurrunnya rasa percaya diri dengan menutup diri dengan lingkungan sekitar sehingga pola emosi pun tidak terlatih dengan baik dalam membentuk dan mengembangkan perilaku prososial baik di dalam lingkungan sekolah maupun lingkungan masyarakat.

Hipotesis kedua, menunjukkan bahwa konsep diri memberikan sumbangan sebesar $-.456 \%$, yang berarti tidak signifikan atau hipotesis ditolak antara konsep diri terhadap perilaku prososial.

Hal ini dapat terjadi karena menurut peneliti terdapat ketidakseimbangan dalam proses pengambilan data yaitu pengambilan data try out di SMA Taman Harapan Malang dengan cara peneliti tidak terjun langsung menjelaskan dan mengambil data dengan situasi sekolah yang tidak mendukung yaitu pada siang hari jam 12.00 yaitu kondisi siswa-i tidak segar, kondisi laper dan kecapekan untuk mengisi skala serta pengambilan data penelitian. Peneliti hanya menitipkan angket/ skala terhadap pihak sekolah untuk ditinjaklanjuti. Pihak sekolah tidak menjelaskan maksut dari angket atau skala yang diberikan tetapi langsung diberikan kepada para siswa untuk mengisinya. Hal ini tentu saja sangat berpengaruh terhadap ketidaksignifikan dari variabel konsep diri terhadap perilaku prososial remaja.

Hasil di atas menggambarkan bahwa siswa di SMA Taman Harapan Malang kurang memiliki konsep diri positif yang seharusnya dapat membantu mereka untuk memiliki banyak teman dan mampu mengembangkan perilaku prososial baik tidak terealisasi dikarenakan indikatorindikator yang menjadi tolak ukur belum 
diwujutkan sepenuhnya dalam aktifitas hidup sehari-hari.

Aditomo dan Retnowati (2004) mengemukakan bahwa konsep diri berpengaruh dalam perilaku remaja dalam kehidupan sehari-hari, remaja dengan konsep diri rendah cenderung berperilaku negatif dalam perilakunya dan merasa tidak dihargai, tidak diterima dan diperlakukan kurang baik oleh orang lain.

Konsep diri merupakan produk prososial dan terbentuk oleh interaksi prososial, selanjutnya berkembang dan berubah melalui interaksi prososial juga.Salah satu tugas perkembangan remaja yang sulit adalah yang berhubungan dengan perilaku prososial diantaranya bergaul dengan teman sebaya di dalam kelompoknya. Jika remaja tidak memahami dan tidak menerima fakta yang bermacammacam tentang dirinya, maka ia tidak akan mengembangkan konsep diri yang tinggi dan menjadi remaja yang tidak mandiri, tidak aktif dan tidak percaya diri.

Konsep diri merupakan penentu tingkah laku, seperti yang dijelaskan oleh Ariety (1967), bahwa konsep diri merupakan dasar dari semua tingkah laku, juga terungkap dari pernyataan Eisenberg dan Delany (1970) bahwa konsep diri sangat menentukan tingkah laku individu sekarang dan masa mendatang serta menentukan pembuatan keputusan dan aspirasi-aspirasi individu bagi masa depannya.

Konsep diri berkembang sesuai dengan usia anak, seperti yang dikemukakan oleh Rogers, 1990), bahwa penemuan tergantung self sudah dimulai pada masa kanak-kanak, tetapi kesadaran tergantung self secara intelektual dan emosional baru muncul pada saat individu mencapai masa remaj. Pada masa remaja, konsep diri telah kokoh bentuknya, walaupun sering ditinjau kembali dengan adanya pengalaman prososial dan pribadi yang baru, berarti terdapat kecenderungan dari beberapa konsep diri tetap, tak berubah atau mempunyai bentuk bentuk relatif tak berubah. Tetapi dengan bertambahnya pengalaman dalam kehidupan selanjutnya, usia dan kematangan dapat merubah konsep diri seseorang dalam kurun waktu tertentu.

Hipotesis ketiga, menunjukkan bahwa kecerdasan emosi memberikan sumbangan sebesar $0.146 \%$, yang berarti terdapat signifikansi atau hipotesis diterima antara kecerdasan emosi terhadap perilaku prososial. Hal ini dapat terjadi karena menurut peneliti terdapat keseimbangan dalam proses pengambilan data try out dan pengambilan data penelitian di SMA Taman Harapan Malang, dapat disimpulkan bahwa siswa-telah memiliki kecerdasan emosi dalam mengembangkan perilaku prososial dengan orang lain.

Hasil di atas menggambarkan bahwa siswa di SMA Taman Harapan Malang telah memiliki kecerdasan emosi positif yang dirasa sangat penting untuk membantu mereka dalam berelasi dengan semua orang. Kesadaran akan pentingya kecerdasan emosi positif dapat terlihat lewat indikatorindikator yang menjadi tolak ukur yang diwujutkan sepenuhnya dalam aktifitas hidup sehari-hari. Unsur-unsur tersebut mampu membentuk rasa percaya diri siswa dalam memproses dan melakukan aktifitas sosial dalam lingkungan sekolah dan lingkungan masyarakat, sehingga perilaku prososial yang baik pula dapat berkembang sesuai dengan kebutuhan masing-masing orang. Jadi, peneliti merasa bahwa dengan kecerdasan emosi yang selalu positif juga dapat membantu membentuk keribadian siswa yang terarah, sehingga mampu menyesuaikan serta menempatkan diri dalam situasi apapun, kapan dan dimanapun mereka berada.

Salah satu faktor yang dapat mempengaruhi munculnya perilaku prososial adalah kecerdasan emosi yang dimiliki oleh individu. Hal ini sejalan dengan hasil penelitian Sabiq dan Djalali 
(2012), ada hubungan yang signifikan antara kecerdasan emosi, kecerdasan spiritual dengan perilaku prososial. Hal ini juga dibuktikan dengan hasil penelitian Asih dan Pratiwi (2010) bahwa kecerdasan emosi dan empati sangat mempengaruhi perilaku prososial seseorang. Seseorang yang secara emosional cerdas akan cepat mengenali emosi yang sedang dialaminya, dan dengan segera dapat mengelola emosi yang muncul (Mathews dkk,2002). Potensi tersebut akan berdampak pada kemampuan menyelesaian permasalahan dengan baik dan memaksimalkan kemampuan penyesuaikan diri dengan lingkungan. Sedangkan tidak ada kompotensi tersebut dapat menyebabkan kekacauan dalam kejiwaan yang dapat berupa depresi (Smith \& Blackwood,2004). Ketidakmampuan mengelola emosi akan menyebabkan seseorang jatuh pada keadaan emosi negatif, hal ini berkaitan erat dengan peningkatan derajat depresi (Verstraeten,2008).

Arbadiati \& Kurniati (2007) mengatakan bahwa individu yang memiliki kecerdasan emosi pasti memiliki kemampuan dalam merasakan emosi, mengelola dan memanfaatkan emosi secara tepat sehingga memberikan kemudahan dalam menjalani kehidupan sebagai makhluk sosial.

Kecerdasan emosi dapat diartikan dengan kemampuan untuk "menjinakkan" emosi dan mengarahkan kepada hal-hal yang lebih positif. Seseorang dapat melakukan sesuatu dengan didorong oleh emosi, dalam arti bagaimana yang bersangkutan dapat menjadi begitu rasional pada suatu saat dan menjadi begitu tidak rasional pada saat yang lain.

\section{KESIMPULAN}

Berdasarkan hasil analisis data yang telah dilakukan, diperoleh hasil bahwa ada pengaruh konsep diri dan kecerdasan emosi terhadap perilaku prososial pada siswa SMA Taman Harapan Malang, dimana semakin tinggi konsep diri dan kecerdasan emosi maka semakin tinggi pula perilaku prososial remaja. Begitu pula sebaliknya yaitu semakin rendah konsep diri dan kecerdasan emosi maka semakin rendah pula perilaku prososial siswa. Hasil perhitungan menunjukan bahwa sumbangan efektivitas konsep diri dan kecerdasan emosi terhadap perilaku prososial sebesar 97\% sedangkan sisanya 3\% dipengaruhi oleh faktor lain. Konsep diri sebesar - $-456 \%$, yang berarti tidak signifikan dan kecerdasan emosi sebesar $0.146 \%$ diterima atau signifikan terhadap perilaku prososial. Berarti dalam meningkatkan perilaku prososial yang lebih baik, kecerdasan emosi lebih memberikan sumbangan dibandingkan konsep diri.

\section{SARAN}

Berdasarkan hasil pembahasan dari penelitian ini, maka saran yang dapat peneliti ajukan adalah sebagai berikut :

a) Bagi Remaja

Remaja mampu mengembangkan konsep diri positif dengan cara menumbuhkan rasa percaya diri menerima kekurangan dan kelebihan dalam diri; juga kecerdasan emosi baik dengan cara menumbuhkan sikap saling menghargai orang yang lebih tua usianya, mampu mengontrol emosi, sopan santun dalam bertutur kata, peduli terhadap teman yang membutuhkan bantuan dan berelasi baik dengan semua orang sehingga perilaku prososial dapat berkembang baik dengan semua orang.

b) Bagi Instansi

SMA Taman Harapan Malang sebagai instansi pendidikan dianjurkan mampu memberikan kontribusi-kontribusi baru dengan cara melakukan pelatihanpelatihan, seperti pelatihan kepribadian yang berhubungan dengan konsep diri dan kecerdasan emosi sehingga remaja memiliki cukup wawasan berpikir yang 
baik dalam mewujudnyatakan serta mengembangkan kemampuan dirinya lewat perilaku prososial dengan semua orang.

c) Bagi Peneliti Selanjutnya

Peneliti selanjutnya yang akan meneliti masalah yang sama agar dapat menyempurnakan variabel yang akan diteliti agar lebih maksimal variabel konsep diri dan kecerdasan emosi terhadap perilaku prososial dan menjadikan hasil penelitian ini sebagai acuan pengembangan penelitian selanjutnya.

\section{DAFTAR PUSTAKA}

Ali, M dan Asrori, M. (2004). Konsep Diri. Psikologi Remaja. Jakarta : Bumi Aksara.

Asih \& Margareta.(2010). Perilaku Prososial ditinjau dari Empati dan Kematangan Emosi.Jurnal Psikologi, 1 (1).

Asih, G.Y., \& Pratiwi, M.M.S. 2010.Perilaku Prososial Ditinjau dari Empati dan Kematangan Emosi.Jurnal Psikologi Universitas Maria Kudus. Vol.1, No.1, Desember 2010 (33-42).

Arbadiati, C \& Kurniati, T. (2007). Hubungan antara Kecerdasan Emosi dengan Kecenderungan Problem Focused Coping pada Sales. Pesat, Vol. 2 No.2.

Azwar, S. (2011).Penyusunan Skala Psikologi. Yogyakarta: Pustaka Belajar.

Baron,\&Byrne, D. (2005).Psikologi Sosial. Edisi Kesepuluh. Jilid 2. Jakarta: Erlangga.

Carlo, R \& Randall, B.A.(2002). The Development of a Measure of Prosocial Behavior for Late Adolescents. Journal of Youth and Adolescence, 31, 1 (Februari,2002), pp. 31-44.

Dayakisni, T \& Hudaniah.(2003). Psikologi Sosial. Edisi Revisi Malang: UMM Press.

Eisenberg, N., Guthrie, I.K., Murpy, B.C., Shepard, S.A., Cumberland, A \& Crlo, G. (2006). Consistency and Development of Prososial Dispositions: A Longitudinal Study. Child Development, 70:1360-1372.

Faturochman \& Pratikto, P. (2012). Kepercayaan Diri, Kematangan Emosi, Pola Asuh Orangtua Demokratis dan Kenakalan Remaja. Persona: Jurnal Psikologi Indonesia. Vol. 1. No.2. September 2012.

Gerungan, W.A. 2000.Psikologi Prososial. Bandung: PT, Refika Aditama.

Goleman, D. (2002). Kecerdasan Emosional untuk Mencapai Puncak Prestasi. Terjemahan Widodo. Jakarta. Gramedia Pustaka Utama.

Hadi, Sutrisno, Metodologi Research Jilid 1, Yogyakarta: Andi Offset, 2000.

Haryati, T.D. (2013). Kematangan Emosi, Religiusitas dan Perilaku Prososial Perawat di rumah Sakit. Persona: Jurnal Psikologi Indonesia.Vol.2. No. 2.162172.

Mappiare, A., 2004, Psikologi Remaja. Surabaya: Usaha Nasional.

Mathews, G., Zeidner M. \& Roberts, R.D. (2002). Emotional Intelligence: Science and Myth Massachusetts: The MTT Press. 
Miraningsih, W. (2013). Interaksi Sosial dan Konsep Diri. Jurnal Universitas Negeri Semarang, April.

Pratikto Herlan. (2012). Hubungan antara Konsep Diri dengan Kompetensi Interpersonal Mahasiswa, Kematangan Emosi, Konsep Diri dan Kenakalan Remaja. Persona, Jurnal Psikologi Indonesia. Vol Dua, No. Satu, hal Delapan.

Ramdhani Neila. (1996). Perubahan Perilaku dan Konsep Diri Remaja yang Sulit Bergaul Setelah Menjalani Pelatihan Ketrampilan Sosial. Jurnal Psikologi. Universitas Gadjah Mada Yogyakarta. No. 1, hal 13.

Rufaida, A.F. (2009). Hubungan Antara Tingkat Kematangan Emosi dengan Tingkah Perilaku Prososial pada Mahasiswa Fakultas Psikologi Universitas Islam Negeri Maulana Malik Ibrahim Malang. Skripsi. Universitas Islam Negeri Maulana Malik Ibrahim Malang.

Rusmawati, Widodo. (2004). Diskrepansi Konsep Diri Ideal dan Kreaativitas pada Remaja. Jurnal Psikologi. UNDIP. Vol Satu, No. Satu, hal 59.

Sabiq, Zamzani \& Djajali, M.As'ad (2012). Kecerdasan Emosi, Kecerdasan Spiritual dan Perilaku Prososial Santri Pondok Pesantren Nasyrul Ulum Pamekasan. Persona, Jurnal Psikologi Indonesia.Vol. 1.No. 2. Hal.53-65. September 2012.
Salovey, P. (2007). Emotional Intelligency: Key Reading On The Mayer and Salovey Model. Port Chester. New York, pp: 1-18.

Santrock, J.W. (2007). Remaja.Edisi kesebelas.Jilid 2. Jakarta: Erlangga.

Sears, O.D., Feedman, A \& Paplau, A.L. (2003).Psikologi Sosial.Jilid dua. Jakarta: Erlangga.

Sobur, A. (2003). Psikologi Umum. Bandung: Pustaka Setia.

Smith, D.J.\& Blackwood, D.H.R. (2004). Depression a young adults.Psychiatri Buletin. United Kingdom: University of Edimburgh. no. 10, pp: 2-14.

Sudjiwanati. (2008). Gaya hidup, konsep diri, dan self esteem. Jurnal Psikovidya.Vol. 12. No. Dua.

Suparno, Eka Setiawati. (2010). Gaya Hidup dan Konsep Diri. Indigenus Jurnal Ilmiah Berkala Psikologi d.h. Kognisi. Vol. 12, No. 1, hal 55.

Verstraeten, K., Vasey, M., Raes. F. \& Bijttebier P. (2008). Temperament and risk for depressive symptoms in adolescence: mediation by rumination and moderation by effortful control. Journal of Abnormal Child Psychology, no. 37, vol. 3, pp: 349-361.

Walgito, B. (2004). Pengantar Psikologi Umum. Yogyakarta: Andi offset.

Yuniardi, S. (2004).Psikologi Lintas Budaya. Malang, UMM: Press. 